\title{
NOVEL SHOCK MICROSTRUCTURES IN ACCESSORY MINERALS FROM THE HAUGHTON DOME, DEVON ISLAND, NUNAVUT, CANADA
}

ERICKSON, Timmons M., Jacobs - JETS, ARES division, NASA Johnson Space Center, 2101 NASA Parkway, Houston, TX 77058 and TIMMS, Nick, TIGeR (The Institute for Geoscience Research), John de Laeter Centre, Department of Applied Geology, Curtin University, Perth, 6102, Australia

The $23 \mathrm{~km}$-diameter, ca. $24 \mathrm{Ma}$ Haughton Dome impact structure in the Canadian Arctic on Devon Island, Nunavut $\left(89^{\circ} 41 \mathrm{~W}, 75^{\circ} 22^{\prime} \mathrm{N}\right)$ occurred within a two layered target composed of a shallowly-dipping $\sim 1700 \mathrm{~m}$ thick succession of Paleozoic limestones and evaporates overlying ca.1.9 Ga high grade gneisses [1, 2]. Within the structure a well preserved impact melt bearing breccia unit contains a variety of shocked clasts from the pre-impact sediments and basement gneisses [3]. Due to their high level of preservation a variety of studies have been undertaken on the clast population of the melt bearing breccia, including characterization of shock within the accessory minerals of the basement lithologies $[4,5]$.

This study presents high resolution electron backscatter diffraction (EBSD) microstructural data for zircon and monazite from historic samples of the basement gneiss, in which bulk shock pressures have been previously constrained based on major phases [4,6]. Shocked zircon and monazite grains have been investigated from shock stage 1b (sample 72110), 2 (7273) and 3 (7192, Dig-9) [4, 6]. At lower shock levels zircon displays planar microstructures consistent with mechanical shock \{112\} twin formation [7] and deviatoric transformation to the high pressure polymorph reidite [8]. Zircon grains from shock stage three show a more chaotic microstructure with multiple orientations of tightly spaced sets of reidite that are variably recrystallized to zircon neoblasts. Monazite from lower shock stages contains a number of mechanical twin orientations that are indicative of shock deformation [9]. At higher shock pressures a lath like structure of interlocking twin orientations has been identified. This microstructure is suggestive of a reversion transformation from a high pressure polymorph [10] and is the first evidence for the transformation of monazite during shock.

References: [1] Osinski et al. (2005) MAPS, 40, 1759-1776, [2] Young et al. (2013) GRL, 40, 3836-3840, [3] Redeker \& Stöffler (1988) MAPS, 23, 185-196, [4] Scharer \& Deutsch (1990) GCA, 54, 3435-3447, [5] Singleton et al. (2015) GSASP 518, 135-148, [6] Metzler et al. (1988) MAPS 23, 197-207, [7] Erickson et al. (2013) Am Min 98, 59-65, [8] Erickson et al. (2017) CMP 176, 6, [9] Erickson et al. (2016) Geology 44, 635-638. [10] Delaey (1991) Pha. Trans Mat. 5, 585-684. 